\title{
A Study on Groundwater Quality Based on Major Ion Chemistry of Jharkhand State in India: (A-Review)
}

\section{ARUN KUMAR PRAMANIK, SANDIP KUMAR DAS and ABHIK CHATTERJEE*}

Department of Chemistry, Raiganj University, Raiganj, 733134, India.

*Corresponding author E-mail: chemistryrgu2018@gmail.com

http://dx.doi.org/10.13005/ojc/370425

(Received: April 14, 2021; Accepted: June 03, 2021)

\begin{abstract}
Groundwater is the prime and major source of drinking water in our world. Groundwater in Jharkhand is also used for drinking, domestic, irrigation, mining and industrial etc. purposes. In Jharkhand some population are suffering from scarcity of pure drinking water and some population have partial facility with drinking water as groundwater of many areas of Jharkhand are contaminated with fluoride, arsenic, heavy metals and iron etc. dangerous chemicals. This review paper focuses on current status of groundwater and contamination of different water quality parameters based on major ion chemistry in Jharkhand. The discussed water quality parameters in this study are water temperature, $\mathrm{pH}$, electrical conductivity, total dissolved solid, total hardness, calcium, magnesium, iron, sodium, potassium, chloride, fluoride, arsenic, carbonate, bicarbonate, phosphate, nitrate and sulphate.
\end{abstract}

Keywords: Jharkhand, Groundwater, Contamination, Ion chemistry, Water quality parameters.

\section{INTRODUCTION}

Water is one of the most precious and abundant compounds in our world. All living bodyies in our universe are impossible without water for their survival. The quantity of water in our planet is huge but we are facing problems for quality of water. All plants and animals are being troubled and human beings suffer from various water borne diseases due to use of contaminated water. Generally in India groundwater was safe and potable for drinking and other purposes of human beings but nowadays due to various causes groundwater is getting contaminated. Hence, few treatments would be required to make groundwater potable in a few areas of India ${ }^{1}$. Therefore, it is also required to have additional sources to fulfill the requirement of fresh water in our country.

Groundwater is also the prime source of drinking water in Jharkhand. The availability of groundwater in many parts of the state is very low and so people in that area have been facing serious problems from scarcity of drinking water. Nowadays the scarcity of good quality portable water is a serious problem in industrial and mining development area of Jharkhand ${ }^{2}$. Rainfall is uneven with time and space and water retention capacity of the soil in the area is very poor. Here, utilisation of groundwater is mainly for drinking purpose and a low percentage of groundwater are used for irrigation, industrialisation and other purposes. In some areas of Jharkhand state, groundwater is

This is an Open Access article licensed under a Creative Commons license: Attribution 4.0 International (CC- BY). Published by Oriental Scientific Publishing Company @ 2018

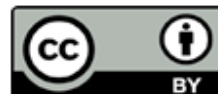


not suitable for human consumption for chemical contamination such as fluoride, heavy metals and arsenic etc. ${ }^{3,4,5,6,7,7,8}$. Mainly the state is covered by forest, pastures-land, waste land and hill area. Various industries such as steel plant, coal mines, thermal power plant etc. are situated in Jharkhand and in the industry area of Jharkhand; the water is heavily contaminated. The groundwater quality of coal mining area of Jharkhand is seriously affected because coal mining operation generate huge amount of waste water ${ }^{2,9}$. People in different mining areas are tremendously suffering from lack of pure drinking water because in that area water are easily polluted due to various mining activities such as deforestation, land degradation, discharge of mine water, disposal of waste materials, washing of rejects, coal washing etc. Some comparative studies reveal that the water quality in urban areas in the world is more contaminated as compared with rural area ${ }^{10}$. Improper awareness, improper education and improper sanitation management for major people are the main causes of water pollution ${ }^{11}$. The unscientific disposal of solid and liquid wastes, the depth of the wells and nature of the geological materials with which the groundwater comes in contact may influence the quality of the groundwater ${ }^{12}$. In our country a huge public awareness program and water plan should be initiated to create a sense of awareness to harvest rainwater and save water around their habitants etc. ${ }^{13}$. The objective of this study is to draw a clean idea about the quality of ground water in Jharkhand.

\section{Study Area}

The selected study area for our review study is Jharkhand (Fig. 1). Jharkhand is one of the newest states of India and located in the eastern part of India.

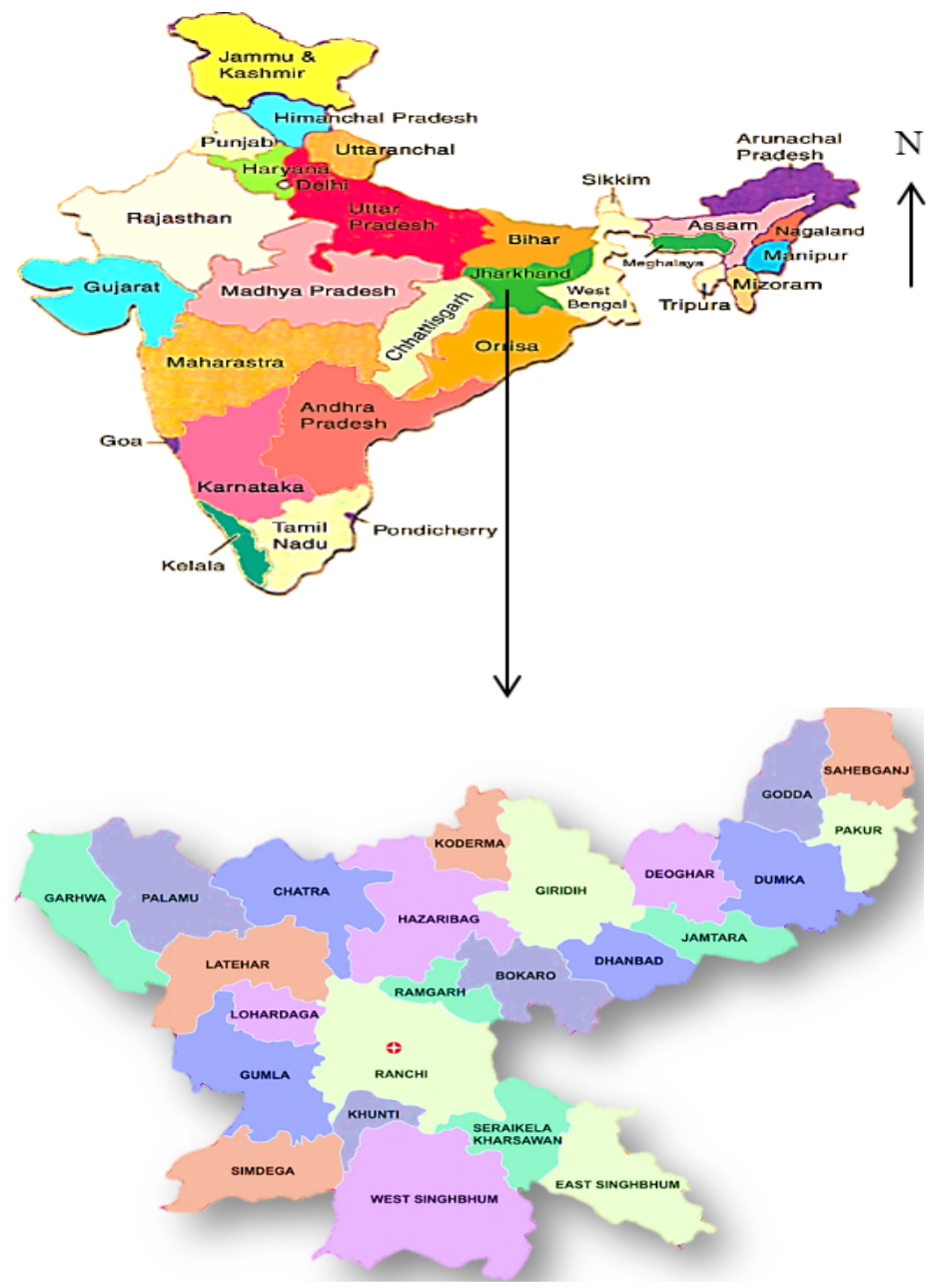

Fig. 1. District of Jharkhand State and Jharkhand State in India 
Here the name of the state "Jharkhand" means "the land of bush or forests" because major portion of the Jharkhand state is still covered by bush or forest. It was created on 15 November 2000 from its parent state Bihar. It is landlocked state and it shares its border with Bihar state to the north, Uttar Pradesh state to the northwest, Chhattisgarh state to the west, Odisha state to the south and West Bengal state to the east. The state has 24 districts, 260 blocks, and 32, 620 villages. Jharkhand state has an area of 79,714 square kilometres and it lies between latitude $21^{\circ} 55^{\prime} 00^{\prime \prime} \mathrm{N}$ and $25^{\circ} 15^{\prime} 00^{\prime \prime} \mathrm{N}$ and longitude $83^{\circ} 15^{\prime} 00^{\prime \prime} \mathrm{E}$ and $87^{\circ} 55^{\prime} \mathrm{E}^{14}$.

It is the $15^{\text {th }}$ largest state by area but by population $14^{\text {th }}$ largest. Maximum portion of the state is covered by forest, pastures-land, waste land and hill area. The state is rich with a vast variety of minerals like iron ore, coal, copper ore, mica, bauxite, graphite, limestone, and uranium. Almost more than $40 \%$ of the mineral resources of India are in the state even though almost $80 \%$ of people in Jharkhand are farmer ${ }^{15}$. Here people are very poor and $39.1 \%$ of its population is below the poverty line ${ }^{16}$. Main occupation of the people in the state is agriculture. The state is mainly rural and almost $76 \%$ of its population live in village ${ }^{16}$. Major cities in the state are Ranchi, Dhanbad, Jamshedpur, Bokaro, Hazaribag, Dumka etc. According to the Indian Census 2011, it has 32.96 million population out of which $28 \%$ is tribal while $12 \%$ of the people belong to scheduled castes. Sex ratio in the state is 947 females to 1000 males $^{14}$.

Major portion of the state lies on the Chota Nagpur Plateau. The state has a wide variety of flora and fauna and huge hills, falls and rivers. The famous waterfalls in the state are Jonha Falls, Hundru Falls, Dassam Falls and Panchghagh Falls. Jharkhand is also known for his beautiful forest. There are five national parks in Jharkhand such as Belta national Park, Dalma wildlife sanctuary, Hazaribug wildlife sanctuary, Udhwa lake birds sanctuary, Singhbhum elephant reserve. The famous hills in the state are Parasnath hill, Rajmahal hill, Netarhat hill, Trikut hill and Tagor hill etc. Here many rivers pass through the state such as Damodar, Barakar, Ajoy, Mayurakshi, Darka, North Koel, South Koel, Sankh, Brahmani and Subarnarekha rivers etc. Some holy place also situated in Jharkhand such as Deoghar for "Baba Dham", Rajrappa for "Chinno Mossta", Parasnath for "Jain temples of Shikharji" and itkhari for "Bhadra Kali Mandir" etc. The Climate of the state varies from humid subtropical in the north to tropical wet and dry in the southeast. The temperatures in Jharkhand usually vary from about $3^{\circ} \mathrm{C}$ to around $45^{\circ} \mathrm{C}$. The annual rainfall of the state is about $1,000-1,500 \mathrm{~mm}$ (40-60inches), out of which $85 \%$ is received through south-western monsoon during the months June-September ${ }^{17}$. According to Central Ground Water Board, net groundwater availability was $5.99 \mathrm{BCM}$, annual replenishable groundwater resource was $6.56 \mathrm{BCM}$, annual groundwater draft for domestic and industrial use was $0.50 \mathrm{BCM}$ and gross annual groundwater draft was $1.35 \mathrm{BCM}$ in 2013 in Jharkhand ${ }^{18}$.

\section{RESULT AND DISCUSSION}

\section{Literature Review of Groundwater Quality in Jharkhand}

In our study various famous international and national research journals have been presented for review of groundwater quality in Jharkhand. Poonam Tirkey et al., (2017) ${ }^{19}$ has reported the groundwater quality of Ranchi city in Jharkhand. They analysed 10 heavy metals namely $\mathrm{As}, \mathrm{Mn}, \mathrm{Ni}$, $\mathrm{Se}, \mathrm{Fe}, \mathrm{Cu}, \mathrm{Cd}, \mathrm{Co}, \mathrm{Cr}$ and $\mathrm{Pb}$ in which $\mathrm{As}, \mathrm{Mn}, \mathrm{Ni}$ and Se were above the acceptable limits as per BIS and WHO standards for drinking purpose. Rakesh Ranjan et al., (2017) $)^{9}$ has reported the status of chemical pollution in groundwater in Dhanbad of Jharkhand. They selected 10 sampling stations and the parameters such as $\mathrm{pH}$, total dissolved solids, turbidity, alkalinity, hardness, chlorides, sulphates, phosphates and iron. They also reported the changes in quality of ground water at the mining areas of Dhanbad due to pollution from coal based effluents. Shiv Kumar Gupta and Kumar Nikhil $(2016)^{2}$ have investigated the contamination of groundwater in the coal mining area of Jharkhand. Prabhunath Singh et al., $(2015)^{20}$ used water quality index method for assessment of groundwater quality of Ranchi township area in Jharkhand. In the study, according to water quality index value, $18 \%$ of water samples fell in the 'Very Good' water category, 67\% water samples fell in 'Good' category and $15 \%$ of water samples fell in the 'Poor' category. Prabhunath Singh et al., (2014) ${ }^{21}$ has also investigated the groundwater for the suitability of drinking, domestic and irrigation purposes in Ranchi township area of Jharkhand. They collected 27 groundwater samples from 
wells and tube wells and analyzed for $\mathrm{pH}$, electrical conductivity (EC), total dissolved solids (TDS) , $\mathrm{Ca}^{2+}$, $\mathrm{Mg}^{2+}, \mathrm{Na}^{+}, \mathrm{K}^{+}, \mathrm{HCO}_{3}^{-}, \mathrm{F}^{-}, \mathrm{Cl}^{-}, \mathrm{NO}_{3}{ }^{-}$and $\mathrm{SO}_{4}{ }^{2-}$. They observed that the groundwater of Ranchi township area was slightly alkaline in nature and suitable for drinking and irrigation. Mousumi Banerjee and Ambarish Mukherjee (2013) ${ }^{22}$ have reported the status of water quality in the proximity of Deogharh Town in Jharkhand. They observed that the groundwater in the area was free from heavy metals like cadmium, lead, chromium and arsenic and fecal bacteria etc. Abhay Kumar Singh et al., (2012) $)^{17}$ has reported a hydro geochemical study of groundwater in Dumka and Jamtara districts of Jharkhand. In their study thirty groundwater samples were collected and analysed parameters were $\mathrm{pH}$, electrical conductivity, total dissolved solids (TDS), total hardness, $\mathrm{F}^{-}, \mathrm{Cl}^{-}, \mathrm{NO}_{3}^{-}$, $\mathrm{HCO}_{3}{ }^{-}, \mathrm{SO}_{4}{ }^{2-}$ and $\mathrm{Ca}^{2+}, \mathrm{Mg}^{2+}, \mathrm{Na}^{+}, \mathrm{K}^{+}$. A. C Pandey et al.,(2012) ${ }^{5}$ also reported high fluoride concentration in Palamu district of Jharkhand. They observed that a very deep aquifer is safer than shallow aquifers and also the artificial recharge may reduce fluoride concentration. Kirti Avishek et al., (2010) ${ }^{4}$ has reported a research work involving an assessment of water quality with special reference to fluoride in Majhiaon block of Garwa district in Jharkhand. They reported that the Majhiaon block in Garwa district of Jharkhand is seriously affected by fluoride. Bishwajit Nayak et al., (2008) 3 investigated on groundwater arsenic contamination and adverse health effects in the Sahibganj district of Jharkhand. They also analysed 367 biological samples (nail, hair, and urine) from affected villages and revealed that an average $88 \%$ of samples were contained by arsenic above the permissible level.

\section{Potential of Groundwater in Jharkhand}

Major portion of the Jharkhand state lies on the Chota Nagpur Plateau and the plateau consisted of Chotanagpur Granite Gneissic Complex (CGGC). Granite-gneiss, schist, phyllite and other rocks belonging to CGGC which covered almost $85 \%$ of the geographical area of the state. The phreatic aquifer in this formation consists of weathered mantle and underlying secondary porosities like fractures, joints and fissures. In general, the thickness of weathered zone varies between 10 and $25 \mathrm{~m}$, however in localized patches it is $>35 \mathrm{~m}$. The weathered zone is the main repository of ground water and the fractures underlying the weathered zones form the potential phreatic aquifer. The potential of groundwater in Jharkhand state is shown in hydrogeological map (Fig. 2) ${ }^{23}$.

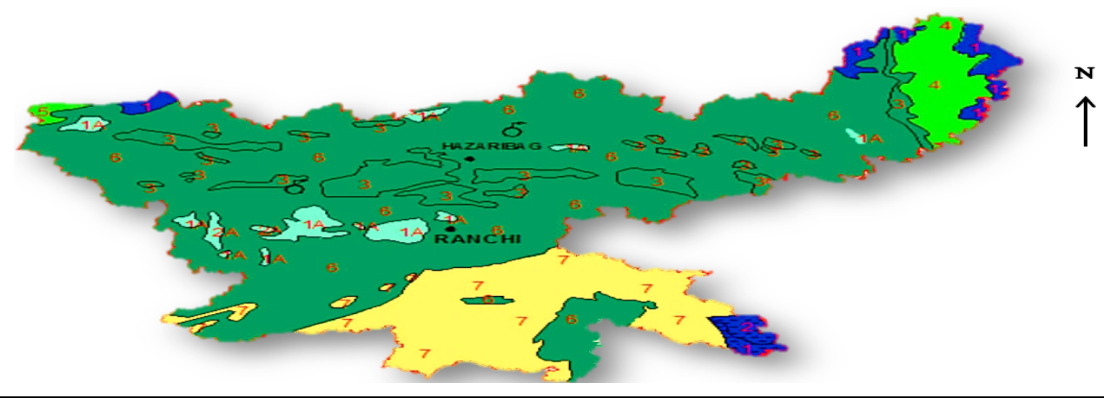

\begin{tabular}{|c|c|c|c|c|}
\hline Colour & Area & Formation & Lithology & Groundwater Potential \\
\hline & 1 & Alluvium & Clay, Slit, Gravel, Pebbles and Calc & $>40 \mathrm{~m}^{3} / \mathrm{h}$ \\
\hline & 2 & Laterites & Laterites and Lithomarge & $1-10 \mathrm{~m}^{3} / \mathrm{h}$ \\
\hline & $2 \mathrm{~A}$ & Tertiary & Sand, Silt, Clay, Pable and Gravel & $10-40 \mathrm{~m}^{3} / \mathrm{h}$ \\
\hline & 3 & Gondwana & Clay, Silt, Grit, Sandstone and Shale & $1->25 \mathrm{~m}^{3} / \mathrm{h}$ \\
\hline & 5 & Vindhyan & Quartzite, Limestone, Sandstone, Dolomite and Shale & $1-25 \mathrm{~m}^{3} / \mathrm{h}$ \\
\hline & 6 & Chotnagpur Gneissc Complex & Gneisses and Granites & $1->25 \mathrm{~m}^{3} / \mathrm{h}$ \\
\hline & 7 & Volcano Sedimentary & Schists, Phyllites, Basic and Acidic Intrusives & $1-15 \mathrm{~m}^{3} / \mathrm{h}$ \\
\hline
\end{tabular}

Fig. 2. Potential of Groundwater i.e., Hydrogeological Map of Jharkhand

\section{Groundwater Level in Jharkhand}

Generally observed groundwater level is categorised into four classes viz., 0-2 m, 2-5 m, 5-10 $\mathrm{m}$ and $>10 \mathrm{~m}$. According to CGWB, the groundwater level (depth) in Jharkhand varied between 0.1 to 21.18 mgbl during 2015-2016. The minimum and maximum depth of groundwater level has been recorded as 0.1 $\mathrm{mgbl}$ at Ranchi and $21.18 \mathrm{mgbl}$ at Gumla. 
In Summer (May 2015), about $67.3 \%$ of the total water level throughout the state varied in the range of $5-10 \mathrm{mbgl}, 18.5 \%$ of the total water level varied in the range of $2-5 \mathrm{mbgl}, 1.8 \%$ of the total water level were $<2$ and $12 \%$ of the water level were $>10$ mbgl (Fig. 3) ${ }^{23}$. In Monsoon (August 2015), 58\% of the total water level throughout the state varied in the range of $5-10 \mathrm{mbgl}, 18.0 \%$ of the total water level varied in the range of $2-5 \mathrm{mbgl}, 22.7 \%$ of the total water level were $<2 \mathrm{mbgl}$ and $1.3 \%$ of the water level were $>10 \mathrm{mbgl}$. Finally it was shown that the groundwater level (depth) of majority areas of the state varied in the range of $2-5 \mathrm{mbgl}$ during the whole year (Fig. 4) ${ }^{23}$.

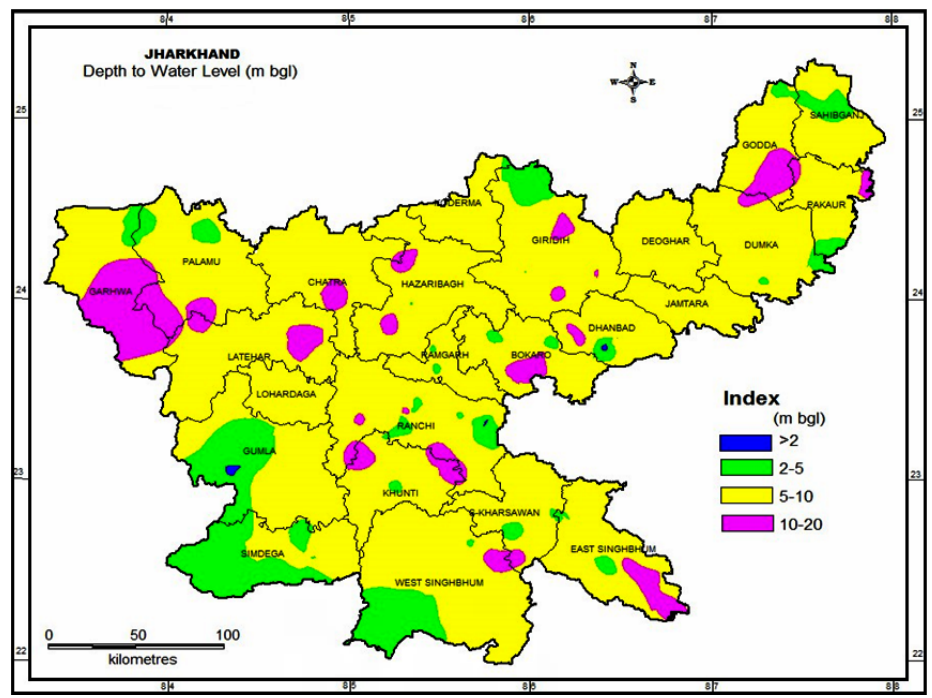

Fig. 3. Groundwater Level (depth) in the Summer in Jharkhand

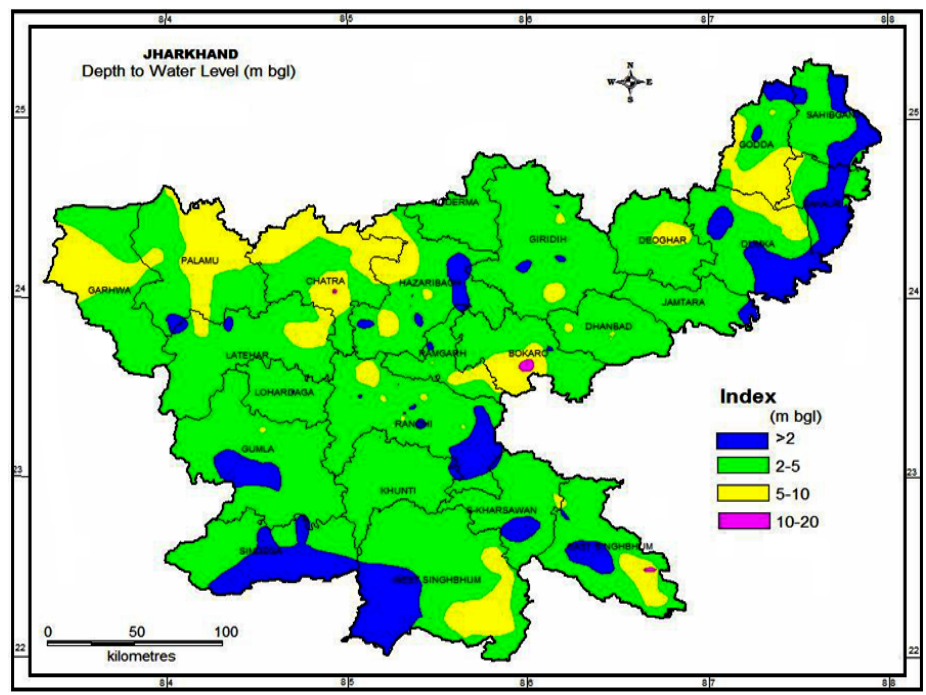

Fig. 4. Groundwater Level (depth) in the Monsoon in Jharkhand

\section{Groundwater Quality of Jharkhand}

Physico-chemical parameter study is very important to get an exact idea about the quality of water and we can compare the results of different physico-chemical parameter values with standard values of $\mathrm{BIS}^{25}$ and $\mathrm{WHO}^{26}$ for drinking purpose. The values of different water quality parameters of groundwater in Jharkhand ${ }^{3,4,5,6,7,8,17,19,23,24}$ and standard values ${ }^{25,26}$ of the water quality parameters for drinking are given in Table 1. Main chemicals contamination in groundwater in Jharkhand are summarised in Table 2.

\section{Assessment of Groundwater Quality Parameters}

Water quality analysis is mainly depended on chemistry. Nowadays, it is very important and 
essential to examine the water quality before it is used for any purposes. Water quality is determined by different physico-chemical parameters and the selection of parameters for testing of water quality is mainly depended upon for what purpose we going to use that water. For our review study the following water quality parameters are considered.

Table 1: Ground Water Quality of Jharkhand

\begin{tabular}{|c|c|c|c|c|c|c|c|}
\hline \multirow[t]{2}{*}{ Parameters } & \multirow[t]{2}{*}{ Unit } & \multicolumn{2}{|c|}{ BISStandard (IS: 10500, 2012) } & \multicolumn{2}{|c|}{ WHO Standard (2017) } & \multicolumn{2}{|c|}{ Measured Values } \\
\hline & & $\begin{array}{c}\text { Acceptable } \\
\text { Limit }\end{array}$ & $\begin{array}{l}\text { Permissible } \\
\text { Limit }\end{array}$ & $\begin{array}{c}\text { Acceptable } \\
\text { Limit }\end{array}$ & $\begin{array}{l}\text { Permissible } \\
\text { Limit }\end{array}$ & $\begin{array}{l}\text { Minimum } \\
\text { Value }\end{array}$ & $\begin{array}{l}\text { Maximu m } \\
\text { Value }\end{array}$ \\
\hline Temperature & ${ }^{\circ} \mathrm{C}$ & - & - & & & & \\
\hline $\mathrm{pH}$ & - & $6.5-8.5$ & - & $7.0-8.5$ & - & 6.7 & 8.68 \\
\hline $\begin{array}{l}\text { Electrical } \\
\text { conductivity }\end{array}$ & $\mu \mathrm{s} / \mathrm{cm}$ & 300 & - & 300 & - & 59.5 & 3321 \\
\hline TDS & $\mathrm{mg} / \mathrm{L}$ & 500 & - & 500 & - & 38.675 & 2158.65 \\
\hline Turbidity & NTU & 10 & 25 & 10 & 25 & & \\
\hline $\begin{array}{l}\text { Total } \\
\text { Hardness }\end{array}$ & $\mathrm{mg} / \mathrm{L}$ & 300 & 600 & 500 & - & 20 & 890 \\
\hline Calcium & $\mathrm{mg} / \mathrm{L}$ & 75 & 200 & - & - & 2 & 668 \\
\hline Magnesium & $\mathrm{mg} / \mathrm{L}$ & 30 & - & - & - & 4 & 120 \\
\hline Alkalinity & $\mathrm{mg} / \mathrm{L}$ & 200 & 600 & 100 & - & & \\
\hline Chloride & $\mathrm{mg} / \mathrm{l}$ & 250 & 1000 & 200 & 600 & 11 & 811 \\
\hline Sulphate & $\mathrm{mg} / \mathrm{L}$ & 200 & 400 & 200 & 400 & 0 & 199 \\
\hline Fluoride & $\mathrm{mg} / \mathrm{L}$ & 1.5 & 1.9 & $1.0-1.5$ & - & 0.15 & 8.68 \\
\hline Sodium & $\mathrm{mg} / \mathrm{L}$ & & & & & 2 & 448 \\
\hline Potassium & $\mathrm{mg} / \mathrm{L}$ & & & & & 0.52 & 12 \\
\hline Nitrate & $\mathrm{mg} / \mathrm{L}$ & & & & & 0 & 316 \\
\hline Silica & $\mathrm{mg} / \mathrm{L}$ & & & & & 2 & 67 \\
\hline Phosphate & $\mathrm{mg} / \mathrm{L}$ & & - & - & - & Nil & \\
\hline Carbonate & $\mathrm{mg} / \mathrm{L}$ & & & & & Nil & \\
\hline Bicarbonate & $\mathrm{mg} / \mathrm{L}$ & & & & & 12 & 479.7 \\
\hline Copper & $\mathrm{mg} / \mathrm{L}$ & 0.05 & - & 1 & - & & \\
\hline Iron & $\mathrm{mg} / \mathrm{L}$ & 0.3 & 1 & & & & \\
\hline Arsenic & $\mathrm{mg} / \mathrm{L}$ & 0.01 & 0.05 & 0.05 & - & 0 & 0.015 \\
\hline
\end{tabular}

Table 2: Main Chemicals Contamination of Groundwater in Jharkhand

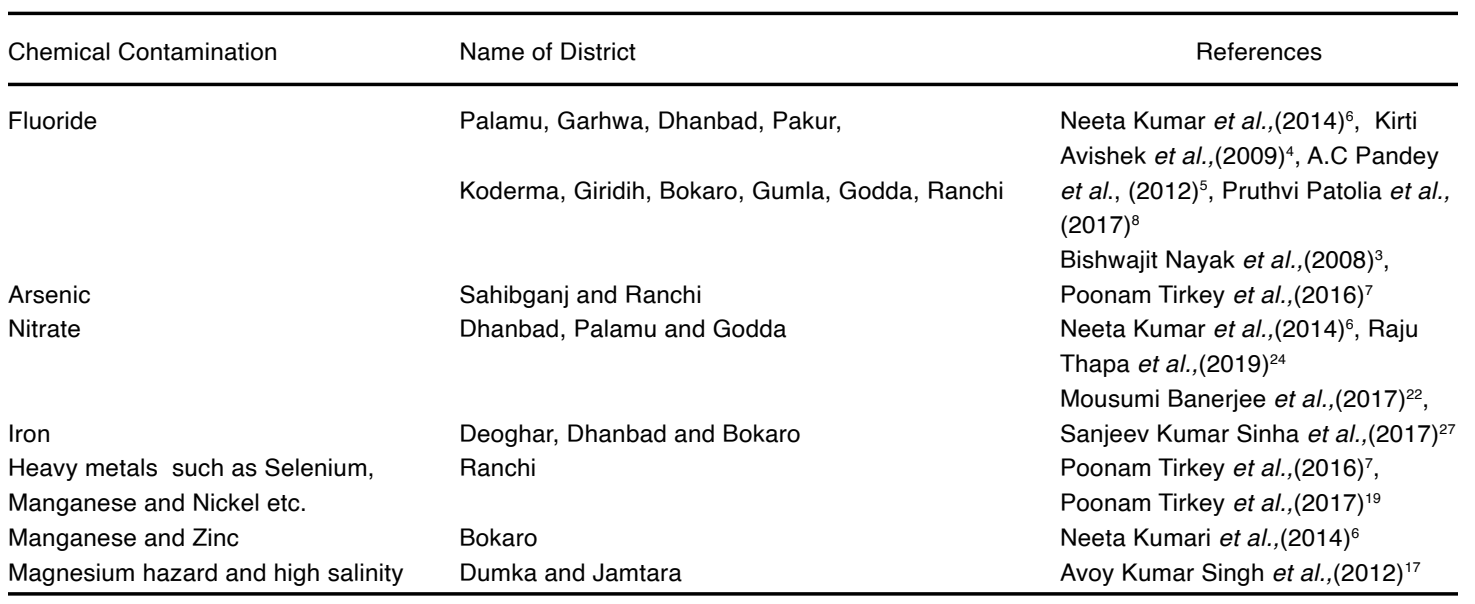

\section{Temperature}

Temperature is one of the most important environment factors and parameters that influence almost all the chemical, physical and biological characteristics of water. Therefore temperature measurement is basically very necessary for water analysis of different sources. Generally the Water temperature of groundwater depends on the depth of the water column, climatic, environment and topographic changes etc. ${ }^{28}$ Kumar Pruthvi et al., $(2017)^{8}$ reported the temperature of groundwater in Ranchi district ranged from 23.1 to $26.9^{\circ} \mathrm{C}$. 
pH

$\mathrm{pH}$ is a prime parameter of water analysis. $\mathrm{pH}$ value indicates the acidity or alkalinity property of the water/solvent/solution. Simply pH is a scale of 0 to 14 where water, $\mathrm{pH}$ of 7 is neutral, $\mathrm{pH}$ less than 7 is acidic and $\mathrm{pH}$ greater than 7 is basic. Poonam Tirkey et al., (2016) ${ }^{7}$ has reported the $\mathrm{pH}$ of ground water in Ranchi city ranged from 6.0 to 7.5 . The $\mathrm{pH}$ of the groundwater in Dhanbad district was found to be ranging from 6.095 to 8.3452 . The value of $\mathrm{pH}$ of groundwater in Dumka and Jamtara districts ranged from 7.24 to 8.25 17. According to Prabhunath Singh et al., (2014) $)^{21}$, the $\mathrm{pH}$ of the groundwater in Ranchi city varied from 7.0 to 8.0 .

\section{Electrical Conductivity}

It is a measure of electric current that water/ solvent/solution carries. Electrical conductivity of water indicates the amount of ions, salts and contaminant present within the water ${ }^{29}$. Electrical conductivity of groundwater in Ranchi city varied from $10 \mu \mathrm{S} / \mathrm{cm}$ to $1520 \mu \mathrm{S} / \mathrm{cm}^{19}$. The overall conductivity of groundwater in Dhanbad district ${ }^{2}$ ranged from $2.2 \mu \mathrm{S} / \mathrm{cm}$ to $3010 \mu \mathrm{S} / \mathrm{cm}, 2016$ ). The average value of electrical conductivity of groundwater in Dumka and Jamtara district was 550 $\mu \mathrm{S} / \mathrm{cm}$ and it varied from $79 \mu \mathrm{S} / \mathrm{cm}$ to $1667 \mu \mathrm{S} / \mathrm{cm}^{17}$. Prabhunath Singh et al., (2014) $)^{21}$ has reported the electrical conductivity of the groundwater in Ranchi city varied from 238 to $1357 \mu \mathrm{S} / \mathrm{cm}$.

\section{Alkalinity}

It is the chemical measurement of ability of water to neutralise acid. The large values of total alkalinity make bitter taste of water. The total alkalinity in water is mainly due to the presence of $\mathrm{OH}^{-}, \mathrm{CO}_{3}{ }^{-}$and $\mathrm{HCO}_{3}{ }^{-}$ions in water ${ }^{30}$. Other salts of weak acid such as ammonium, phosphate, silicates, borates and organic bases are also responsible for total alkalinity of water. The value of total alkalinity of groundwater in Ranch City ranged from $28 \mathrm{mg} / \mathrm{L}$ to $340 \mathrm{mg} / \mathrm{L}^{19}$.

\section{Total Hardness}

Hardness of water is also an important characteristic to determine quality of water from different sources. The causes of hardness in fresh water mainly due to carbonates, bicarbonates, chlorides and sulphates of calcium and magnesium. Theoretically the total hardness of water is defined as the sum of calcium and magnesium hardness in $\mathrm{mg} / \mathrm{lit}$ as $\mathrm{CaCO}_{3}$. A high concentration of hardness may be due to leaching from of the soils or due to the high background concentration of the water. High concentration of hardness may cause the problem of heart disease and kidney stones. According to Poonam Tirkey et al.,(2017) ${ }^{19}$, the hardness of groundwater varied between 32 to $508 \mathrm{mg} / \mathrm{L}$ in Ranchi City. The value of total hardness of groundwater in Dumka and Jamtara districts ranged from 19 to 531 $\mathrm{mg} / \mathrm{L}^{17}$. Prabhunath Singh et al., (2014) ${ }^{21}$ has reported the total hardness of the groundwater in Ranchi city ranged from 120 to $598 \mathrm{mg} / \mathrm{L}$.

\section{Calcium and Magnesium}

Calcium and magnesium are very important parameters for water analysis. Hardness of water is also depended on concentration of calcium and magnesium. The concentration of calcium and magnesium in groundwater of Dumka and Jamtara districts ranged from 3.4 to $102.5 \mathrm{mg} / \mathrm{L}$ and 2.6 to $66.9 \mathrm{mg} / \mathrm{L}$ respectively ${ }^{17}$. Prabhunath Singh et al., $(2014)^{20}$ has reported the concentration of calcium and magnesium varied from $21.8 \mathrm{mg} / \mathrm{L}$ to $164 \mathrm{mg} / \mathrm{L}$ and $9.8 \mathrm{mg} / \mathrm{L}$ to $46 \mathrm{mg} / \mathrm{L}$ respectively in Ranchi city.

\section{Iron}

Iron is also a metal that is found in groundwater. Iron in water is not so toxic but concentration over permissible limit has some adverse effect in human body. Iron concentration in the groundwater of Dhanbad district $^{2}$ ranges from $0.039 \mathrm{mg} / \mathrm{L}$ to $1.40 \mathrm{mg} / \mathrm{L}$.

\section{Total Dissolved Solid (TDS)}

Total dissolved solids are the measure of total dissolved salts, ions, minerals and materials in water. Simply purity of drinking water is measured in terms of TDS. The differences in TDS values may be dependent on geological formations, hydrological processes and prevailing mining conditions in the region ${ }^{19}$. The total dissolved solids (TDS) values of groundwater ranged from 51 to $772 \mathrm{mg} / \mathrm{L}$ in Ranchi city $^{19}$. The TDS of groundwater in Dhanbad district ${ }^{2}$ were varied from $58.2 \mathrm{mg} / \mathrm{L}$ to $1489 \mathrm{mg} / \mathrm{L}$. The average value of total dissolved solid (TDS) of groundwater was $348 \mathrm{mg} / \mathrm{L}$ in Dumka and Jamtara districts and it ranged from 19 to $531 \mathrm{mg} / \mathrm{L}^{17}$. Prabhunath Singh et al., (2014) has reported the concentration of total dissolved solids (TDS) in the groundwater of Ranchi city ranged from 200 to $1157 \mathrm{mg} / \mathrm{L}$. 


\section{Carbonate}

Carbonate is directly or indirectly related with $\mathrm{pH}$ and alkalinity of water. Whenever the value of $\mathrm{pH}$ of water reaches to 8.3 , the presence of carbonate is indicated. Carbonates in water are converted into bicarbonates at lower $\mathrm{pH}$ than 8.3. The concentration of carbonate ions in different ares of Jharkhand is zero.

\section{Bicarbonate}

Bicarbonate is one of the most abundant anion in freshwater. The concentration of bicarbonate in groundwater of Dumka and Jamtara districts ranged from 37 to $258 \mathrm{mg} / \mathrm{L}^{17}$. Prabhunath Singh et al.,(2014) $)^{20}$ has observed the concentration of bicarbonate varied from $90 \mathrm{mg} / \mathrm{L}$ to $488 \mathrm{mg} / \mathrm{L}$.

\section{Nitrate}

Nitrate is an important parameter in water and it is naturally occurring inorganic ion present in our environment. Nitrate in groundwater is a prime indicator of anthropogenic pollution especially as it indicates inputs of detergent, soap, toothpaste, shampoo, fertiliser used in the domestic and agricultural fields. The nitrate concentration of groundwater in Ranchi city is below the acceptable limits of BIS $(45 \mathrm{mg} / \mathrm{L})^{19}$. In Dumka and Jamtara districts the concentration of nitrate in groundwater ranged from 0.1 to $191.9 \mathrm{mg} / \mathrm{L}^{17}$. According to Prabhunath Singh et al.,(2014) $)^{20}$ the concentration of nitrate in the analysed groundwater samples of Ranchi city varied between 2.5 to $53.7 \mathrm{mg} / \mathrm{L}$.

\section{Chloride}

Chloride is one of the most abundant inorganic anion in natural water of various sources. Generally low existence of chloride is shown in normal fresh water due to the dissolution of salts but in sea water chlorine is predominant as an ion in the water. According to Poonam Tirkey et al.,(2017) ${ }^{19}$ chloride values in the ground water of rural, urban and peri-urban areas of Ranchi city in the monsoon season varied from $2 \mathrm{mg} / \mathrm{L}$ to $200 \mathrm{mg} / \mathrm{L}$. The chloride concentration in groundwater of Dumka and Jamtara districts ranged from 1.2 to $302 \mathrm{mg} / \mathrm{L}^{17}$. Prabhunath Singh et al.,(2014) ${ }^{20}$ has reported the chloride concentration in the groundwater of Ranchi township area varied from 30 to $176.3 \mathrm{mg} / \mathrm{L}$.

\section{Sulphate}

Sulphate is an important parameter in water. However, the sulphate concentration in water of the study area is within the maximum allowable limit. Generally many sulphate compounds such as sulphate ores, gypsum, shale, industrial waste etc. are readily soluble in water and so sulphate ions usually occur in natural waters. Atmospheric sulphur dioxide comes from metallurgical industry (by the metallurgical roasting processes) and the combustion of fossil fuels by vehicles, engines and industries may also contribute to the sulphate compounds of water directly or indirectly. The sulphate concentration of groundwater in Ranchi city was varied between 0 and $268 \mathrm{mg} / \mathrm{L}^{19}$. The sulphate concentration value of groundwater in Dumka and Jamtara districts ranged from 0.7 to $134 \mathrm{mg} / \mathrm{L}^{17}$. Prabhunath Singh et al., (2014) ${ }^{21}$ has reported the concentration of sulphate in groundwater of Ranchi city varied from 10 to $126 \mathrm{mg} / \mathrm{L}$.

\section{Phosphate}

The increased application of fertilizers, use of detergents and domestic sewage greatly contribute to the heavy loading of phosphorous in the water ${ }^{30,31}$. According to Poonam Tirkey et al., (2017) ${ }^{19}$ phosphate in groundwater of Ranchi city was seen to be between 0.004 and $0.16 \mathrm{mg} / \mathrm{L}$. Phosphate concentration variability irrespective of zone and sources (well or bore well) was less in the study area.

\section{Sodium}

Sodium concentration in water is an important factor for drinking and irrigation purposes. Sodium plays an important role in plants, animals and human body system. Generally extremely high sodium concentration is observed in sea water and normal fresh water bears low concentration of sodium. Sodium concentration of groundwater in ranchi city varied from $18.2 \mathrm{mg} / \mathrm{L}$ to $303 \mathrm{mg} /$ $\mathrm{L}^{19}$. In Dumka and Jamtara districts of Jharkhand sodium concentration ranged from 6.6 to $70.8 \mathrm{mg} /$ $\mathrm{L}^{17}$. Prabhunath Singh et al.,(2014) ${ }^{21}$ has reported sodium concentration of groundwater in Ranchi city varied from 14.2-75.2 $\mathrm{mg} / \mathrm{L}$.

\section{Potassium}

It is also an important parameter of drinking water and irrigation water. Growth of plants and production crops depends also on potassium concentration in water and soil. Potassium concentration of groundwater in Ranchi city varied from $0.2 \mathrm{mg} / \mathrm{L}$ to $22.4 \mathrm{mg} / \mathrm{L}^{19}$. The value of potassium concentration in groundwater of Dumka and Jamtara 
districts ranged from 0.8 to $18 \mathrm{mg} / \mathrm{L}^{17}$. Prabhunath Singh et al.,(2014) ${ }^{21}$ has reported potassium concentration in groundwater of Ranchi city ranged from $1.6-19.3 \mathrm{mg} / \mathrm{L}$.

\section{Fluoride}

Fluorine is present in natural water or contaminated water as fluoride. Usually fluoride concentration in natural water depends on geological formation except pollution due to industries or other. The main sources of the fluoride found in groundwater may be naturally occurring from the breakdown of rocks, soil minerals or weathering (geogenic) and waster due to human activities (anthropogenic) ${ }^{19}$. Fluoride may be an essential element for animals and humans but excessive consumption of fluorine ( $>2 \mathrm{mg} / \mathrm{L}$ ) causes a dental disease (dental cavities for children) known as fluorosis while regular consumption in excess may give rise to bone fluorosis and other skeletal fluorosis. Poonam Tirkey et al.,(2017) ${ }^{19}$ has reported the fluoride concentration varied from 0 to 2.19 $\mathrm{mg} / \mathrm{L}$ in Ranchi city. The fluoride concentration of groundwater in Dumka and Jamtara districts ranged from 0.17 to $1.07 \mathrm{mg} / \mathrm{L}^{17}$. Kirti Avishek et al., $(2009)^{4}$ has reported high fluoride concentration at Majhiaon block in Garwa district of Jharkhand. A.C Pandey et al.,(2012) ${ }^{5}$ also observed high fluoride concentration in groundwater of Palamu district of Jharkhand. Prabhunath Singh et al.,(2014) ${ }^{20}$ has reported fluoride concentration in groundwater of Ranchi city varied from 0.1 to $1.4 \mathrm{mg} / \mathrm{L}$.

\section{CONCLUSION}

Quality and quantity of groundwater are decreasing with time in everywhere in the world and the effects for that are not only devastating to human beings, but also to all living bodyies in the world. In our present study, a review of ground water resources of Jharkhand has been carried out to define the groundwater quality system based on major ion chemistry. This will help current water resources planning of Jharkhand and provide an over all idea for contamination of ground water in Jharkhand. In general major chemical constituents are within permissible limit except fluoride, nitrate, iron, selenium, manganese, nickel and zinc contamination in some districts and arsenic contamination in Sahebganj district. Thus it is observed that the quality of groundwater in the entire state is suitable for drinking, irrigation and industrial purposes except in arsenic, fluoride and others chemical infested areas. The present review study will give an acute awareness among the people of Jharkhand about the quality of groundwater. Proper awareness program and water management plant for groundwater quality is needed in Jharkhand which can help the individual and the community to use pure drinking water and minimize water pollution.

\section{ACKNOWLEDGEMENT}

The senior author would like to acknowledge Chemistry Department, Raiganj University, West Bengal, India for providing technical and library support during conducting this study and preparing the manuscript. Thankful to Central Ground water Board, Government of India for giving permission to reproduce Fig. 2, 3 and 4 .

\section{Conflict of interest}

No potential conflict of interest was reported by the author(s).

\section{REFERENCES}

1. Tyagi, S.; Singh, P.; Sharma, B.; Singh, R. Applied Ecology and Environmental Sciences., 2014, 2(4), 94-99.

2. Gupta, K.S.; Kumar, N.; Dubey, U. International Journal of Advance Research in Science and Engineering., 2016, 5(03), 534-539.

3. Nayek, B.; Das, B.; Mukherjee, C.S.; Pal, A.; Ahamed, S.; Hossain, M.A.; Maity, P.; Dutta, N.R.; Dutta, S.; Chakarborti, D. Toxicological \& Environ. Chemistry., 2008, 90(4), 673-694.

4. Kirti, A.; Pathak, G.; Nathawat, M.S.; Jha, U.; Kumari, N. Environmental Monitoring Assessessment., 2010, 167, 617-623.
5. Pandey, A.C.; Shekhar, S.; Nathwat, M.S. Indian J. of Applied Science., 2012,12(9), 882- 887.

6. Kumari, N.; Pathak, G. Journal of Engineering Research and Applications., 2014, 4(3), 65-77.

7. Tirkey, P.; Bhattacharya, T.; Chakraborty, S. Current Science., 2016, 110(1), 10.

8. Patolia, P.; Sinha, A. ArabJ Geosci., 2017, 10, 381.

9. Ranjan, R.; Sinha, K.S. International Journal of Scientific \& Engineering Research., 2017, 8(6), 565-567.

10. Kannel, P.R.; Lee, S.; Lee, Y.; Kannel, S.R.; Khan, S.P. Environmental Monitoring Assessesment., 2007, 132, 93-110. 
11. Mutiu, A.;Alabi, G.I.; Olalekan, H.O.; Rita, M.S.; Temitope, O.; Folake, G.O.; Stella, O. IOSR Journal Of Environmental Science, Toxicology And Food Technology., 2013, 6(3), 57-63.

12. Ambiga, K.; Anna, D.R. The International Journal of Engineering and Science., 2013, 2(01), 263-268.

13. Khwaja, M.; Aggarwal, A.V. Current World Environment., 2014, 9(3), 851-857.

14. Jharkhand at a glance, https://www.jharkhand. gov.in/.

15. Department of Mines \& Geology, Government of Jharkhand, Minerals Resources of Jharkhand, http://www.jharkhandminerals. gov.in/portletContent/30/40.

16. https://www.britannica.com/place/Jharkhand/ Government-and-society (27.12.2019).

17. Singh, K.A.; Mondal, G.C.; Singh, T.B.; Singh, S, Tewary, B.K.; Sinha, A. Environ Earth Sci., 2012, 67, 2175-2191.

18. Central Ground Water Board, (CGWB), Government of India, Jharkhand, http:// cgwb.gov.in/District_Profile/Jharkhand_ districtprofile.html.

19. Tirkey, P.; Bhattacharya, T.; Chakarborty, S.; Baraik, S. Groundwater for Sustainable Development., 2017, 5, 85-100.

20. Singh, P.; Tiwari, K.A.; Singh, K.P. International Journal of Chem Tech Research., 2015, 07 (01), 73-79.
21. Singh, K.P.; Tiwari. K.A.; Singh, K.P. Current World Environment., 2014, 9(3), 804-813.

22. Banerjee, M.; Mukherjee, A. J. Sci. Res., 2013, 4(2), 87-92.

23. Ground water year book Jharkhand, Government of India, Ministry of water resources, RD \& GR central ground water board., 2015-2016,

24. Thapa, R.; Gupta, S.; Kaur, H.; Baski, R. Hydro Research., 2019, 2, 60-68.

25. Indian Standard, Drinking Water-Specification, (Second Revision), (2012), IS 10500, ICS 13.060.20.

26. WHO Guidelines for Drinking Water Quality. $4^{\text {th }}$ edition. World Health Organization., 2017.

27. Sinha, K.S. International Journal of Scientific \& Engineering Research., 2017, 8(6), 565567.

28. Sagar, S.S.; Chavan, R.P.; Patil, C.L.; Shinde, D.N.; Kekane, S.S. International Journal of Chemical Studies., 2015, 3(4), 24-28.

29. Pramanik, K.A.; Majumdar, D.; Chatterjee, A. Water Science., 2020, 34(1), 85-97.

30. Pramanik, K.A.; Majumdar, D.; Chatterjee, A. Analytical Chemistry Letters., 2020, 10(5), 684-702.

31. Kumar, A.; Sharma, M.P. Proceedings of 2nd The IRES International Conference, Berlin, Germany, $13^{\text {th }}$ June 2015, ISBN: 978-9385465-28-4. 